\title{
Announcement: Award-winning papers in 2005
}

Papers published in Bridge Engineering are eligible for awards from the Institution of Civil Engineers. Papers from any of the ICE journals can be nominated for several awards. In addition, each journal has awards dedicated to their specific subject area.

On Wednesday 1 November 2006, outgoing ICE president Gordon Masterton presented awards to the following papers published in Bridge Engineering in 2005. The editorial panel nominated their best papers and an awards committee chaired by John Burland allocated the awards.

The John Henry Garrood King Medal, presented for the best paper on bridges, was awarded to: Sanders P. A. and Firth I. P. T. Design and construction of the Sail Bridge, Swansea. Proceedings of the Institution of Civil Engineers, Bridge Engineering, 2005, 158, No. 4, 145-153.

The Telford Premium (1) prize, presented for the second best paper on bridges, was awarded to: Smith D. A. Refurbishment of the old Medway Bridge, UK. Proceedings of the Institution of Civil Engineers, Bridge Engineering, 2005, 158, No. 3, 129-139.

The Overseas Prize (2) for the second best paper on an overseas project was awarded to: Ekeberg P. K. and Søyland K. Filsa Bridge, Norway-a record-breaking timber bridge. Proceedings of the Institution of Civil Engineers, Bridge Engineering, 2005, 158, No. 1, 1-7.

The Bill Curtin Medal, presented for the best paper describing innovative design, was awarded to: Kermani A. and Freedman G. Performance of a stress-laminated-timber arch bridge. Proceedings of the Institution of Civil Engineers, Bridge Engineering, 2005, 158, No. 4, 155-164.

The Reed and Malik Medal, presented for the best paper on construction aspects of a civil engineering project, was awarded to: Place D., Farooq I. and Carter S. A34 Chievely/M4 Junction 13 improvement: design. Proceedings of the Institution of Civil Engineers, Bridge Engineering, 2005, 158, No. 1, 15-23. 